\title{
ENTREPRENEURSHIP AND ECONOMIC DEVELOPMENT: A LITERATURE REVIEW
}

\author{
Nguyen Van Phuc \\ Ho Chi Minh City Open University
}

(Received: 20/04/2014; Revised: 02/06/2014; Accepted: 28/7/2014)

\begin{abstract}
This paper makes a comprehensive review of entrepreneurship on economic development in economic theory. It indicates how entrepreneurship is crucial for economic development. The role of entrepreneurship on economic development originated from different understandings on the nature of economic system. It is argued that the role of the entrepreneur has been moved out of the neoclassical model because a crucial assumption of the model is that decision-making merely involves marginalist calculation to optimise production, based upon public information supplied by the price system. The explanation for the phenomenon of economic development depends on how we understand the nature of the market process. In this respect, the economics of entrepreneurship is different from mainstream economics. For mainstream economics, the market is generally characterised by equilibrium. For the economics of entrepreneurship, the market process is characterised by disequilibrium. The review of literature indicates that entrepreneurship has different essential features that all are critical to economic development and the market process. They are Kirzner's arbitragers or Schumpeter's innovators. They are Knight's uncertainty-bearing people. They assume managerial or leadership roles and thus function as the main allocators of scarce resources in the economic system as identified by Baumol and Casson. Entrepreneurship is a solution to X-inefficiency, by motivating efforts within firms as argued by Leibenstein. All this has important implications for economic development. Millions of business decisions made by numerous entrepreneurs daily affect an economy a great deal. The pace of economic development ultimately depends on such endeavour of numerous entrepreneurs. It is normally believed that the lagging behind of many developing countries lies in their lack of entrepreneurship. The policy implication is that, in order to have good economic development, governments should create a favourable environment for entrepreneurs to carry out above-mentioned functions in the economy.
\end{abstract}

Keywords: Entrepreneurship, Economic Development, Innovation, Creative Destruction.

\section{Introduction}

Entrepreneurship has been long recognised as an important factor of economic development, dating back from Cantillon (1755) to Schumpeter (1911). The entrepreneurial spirit for innovation and risktaking are indispensable inputs for modern capitalism to flourish. However, recent growth theories have ignored this factor. The role of entrepreneurship on economic development originated from different understandings on the nature of economic system. It is argued that the role of the entrepreneur has been moved out of the neoclassical model because a crucial assumption of the model is that decision-making merely involves marginalist calculation to optimise production, based upon public information supplied by the price system. The explanation for the phenomenon of economic development depends on how we understand the nature of the market process. In this respect, the economics of entrepreneurship 
is different from mainstream economics. For mainstream economics, the market is generally characterised by equilibrium; and mainstream growth economics is mainly about equilibrium growth, i.e., the movement from one equilibrium point to another equilibrium point. For the economics of entrepreneurship or Austrian economics, the market process is not characterised by equilibrium but characterised by disequilibrium. The main reasons for the market to be characterised by disequilibrium are those concerning with the issues of imperfect information and imperfect knowledge, ignorance, errors of market participants and the incessant innovation created by entrepreneurs. Therefore, in this perspective, to understand the growth phenomenon is to understand how the disequilibrium process comes about and what makes it move. The stress here is on the role of entrepreneurship as the main driving force for the market process, hence economic development. Schumpeter's theory emphasises entrepreneurship as a disequilibrating force (through innovation) which drives the economic system forward. Kirzner (1973, 1997a,b) stresses entrepreneurship as an equilibrating force which exploits unnoticed opportunities, correcting errors in the market process. Both kinds of entrepreneurship bring about higher values for resources used in the economy, and hence economic development.

It is normally believed that the lagging behind of many developing countries lies in their lack of entrepreneurship (for example, Hirschman, 1958). In his Stages of Economic development, Rostow (1960) argued that entrepreneurship was a crucial factor for the take-off. For rich countries, this is not a problem, but for many developing countries it is a serious problem. He said: "It is evident that the take-off requires the existence and the successful activity of some group in the society which is prepared to accept innovations...[T] pre problem of entrepreneurship in the take-off has not been profound in a limited group of wealthy agricultural nations whose populations derived by emigration mainly from north-western Europe. There the problem of take-off was primarily economic; and when economic incentives for industrialization emerged commercial and banking groups moved over easily into industrial entrepreneurship. In many other countries, however, the development of adequate entrepreneurship was a more search social process" (Rostow, 1960, p. 50).

For developing countries, the catchingup role of entrepreneurship should be emphasised. Most of developing countries do not invent but learn to master technologies and practices from developed countries. Normally, an advanced technology or a good practice is not new to the world but new to a particular developing country. Schumpeter's innovators are therefore important in mastering these technologies and practices. The ability of local entrepreneurs to imitate and learn rapidly is a critical factor for economic success. To achieve rapid and long-term growth, developing countries have often developed industries that did not exist before in their countries or which they did not have the capacity to produce. It is in the process of imitation, learning and innovation from advanced technologies and practices that their comparative advantages have gradually changed. Without Schumpeter's innovators, it is difficult to achieve this transformation. In summary, all the functions of the entrepreneur are essential for any market economy. Millions of business decisions made by numerous entrepreneurs daily affect an economy a great deal. The stress on entrepreneurship has important implications for economic development. The pace of economic development ultimately depends on such endeavour of numerous entrepreneurs.

\section{The Concept of Entrepreneurship}

The definition of entrepreneurship is rather diverse among scholars and academic disciplines. Below are the main definitions of entrepreneurship.

According to Casson (1987), the term 'entrepreneur' was first introduced into economic theory by Canlillon (1755) meaning 'an undertaker' of business activities. In this 
sense, an entrepreneur is a person who undertakes to establish and run a business and bears the risks of it. Knight (1921) defined entrepreneurs as risk-taking people. For Knight, each business situation is unique, and the relative frequencies of past events cannot be used to evaluate the probabilities of future outcomes. These are uncertainties that can not be insured by insurance markets. Those who make decisions with such uncertainties have to incur all the costs.

Schumpeter (1951, [original 1911]) defined entrepreneurship as " the carrying out of new combinations". The persons who carry out such new combinations are called entrepreneurs. This concept of entrepreneurship covers: "(1) The introduction of a new good - that is one with which consumers are not yet familiar - or of a new quality of a good. (2) The introduction of a new method of production, that is one not yet tested by experience in the branch of manufacture concerned, which need by no means be founded upon a discovery scientifically new, and can also exist in a new way of handling a commodity commercially. (3) The opening of a new market, that is a market into which the particular branch of manufacture of the country in question has not previously entered, whether or not this market has existed before. (4) The conquest of a new source of supply of raw materials or halfmanufactured goods, again irrespective of whether this source already exists or whether it has first to be created. (5) The carrying out of the new organisation of any industry, like the creation of a monopoly position (for example through trustification) or the breaking up of a monopoly position" (Schumpeter, 1951, p. 66). In short, Schumpeterian entrepreneurs are innovators in the economic system. Schumpeter was also very clear about who were entrepreneurs and who were not. Schumpeter distinguished entrepreneurs from capitalists. Capitalists are just those who own capital. They do not necessarily carry out entrepreneurial activities. Entrepreneurs may happen to be capitalists, but it is not necessarily so. When entrepreneurs carry out 'new combinations', they need capital, and they borrow capital from capitalists. Capitalists are just moneylenders, no more.

Kirzner (1973, 1997a, 1997b) has developed the theory of entrepreneurship basing on the works of L. V. Mises and F. A. Hayek. Like Schumpeter, Kirzner defines entrepreneurship basing on the perception that the market process is a disequilibrium process rather than an equilibrium one. However, unlike Schumpeter, Kirzner stresses entrepreneurship as equilibrating force towards equilibrium. A state of market disequilibrium is characterised by countless untapped opportunities. It is entrepreneurs who are 'alert' to these opportunities. Entrepreneurs are defined as those who first notice these untapped opportunities and exploit them. It is through this entrepreneurial discovery that eventually brings about equilibrium. He says: "my own treatment of the entrepreneur emphasises the equilibrating aspects of his role. I see the situation upon which the entrepreneurial role impinges as one of inherent disequilibrium rather than of equilibrium - as one churning with opportunities for desirable changes rather than one of placid evenness. Although for me, too, it is only through the entrepreneur that changes can arise, I see these changes as equilibrating changes. For me the changes the entrepreneur initiates are always toward the hypothetical state equilibrium; they are changes brought about in response to the existing pattern of mistaken decisions, a pattern characterised by missed opportunities" (Kirzner, 1973, p. 73). It is this entrepreneurial alertness that moves "resources from one line of production to another, from less productive uses towards more productive uses" (Kirzner, 1997a, p. 42).

In agreement with Schumpeter, both Mises and Kirzner argued that entrepreneurs were not necessarily capitalists. In fact, the alertness or entrepreneurial discovery does not presuppose any initial asset ownership. Kirzner maintains: "ownership and entrepreneurship are to be viewed as completely separate functions...Purely entrepreneurial decisions are by definition reserved for decision-makers who own nothing 
at all" (Kirzner, 1973, p. 47). In addition, entrepreneurship is inherent in human action rather than in men. Mises clarified: "Economics, in speaking of entrepreneurs, has in view not men, but a definite function. This function is not the particular feature of a special group or class of men; it is inherent in every action and burdens every actor" (Mises, 1949 , p. 253). In this respect, Kirzner's notion of entrepreneurs is the same as that of Schumpeter.

Although Schumpeter's and Kirzner's theories of entrepreneurship seem to be different, the two are complementary in explaining the market process. In short, the complement between Schumpeterian entrepreneurship and Kirznerian entrepreneurship is that the creation of potential may be seen as Schumpeterian and its realisation as Kirznerian (Wennekers et al., 1997). Schumpeterian entrepreneurship incessantly creates new opportunities by carrying out 'new combinations' and Kirznerian entrepreneurship assures that these newly-created opportunities will be properly exploited to bring about higher values for the economy, thereby creating economic growth. Schumpeterian entrepreneurship is seen as creative responses, whereas Kirznerian entrepreneurship is seen as adaptive responses (Yu, 1997).

Leibenstein (1968) identified two types of entrepreneurs. The first one is the Schumpeterian entrepreneur who makes 'new combinations'. The other one is related to managerial functions of entrepreneurs (establishing and running business or allocating resources in routine ways). Leibenstein observed that many firms operating well within their production possibility frontier. This implies that there is a potential to more efficiency. He refers to this as X-inefficiency. Leibenstein attributed much of the cause of X-inefficiency to differential and inadequate motivation and information usage (Binks and Vale, 1990). Less motivation and lack of information increase the level of $\mathrm{X}$-inefficiency. Therefore, the entrepreneurial spirit can motivate more efforts for better efficiency and less X-inefficiency. Leibenstein also argued that there was no one-to-one correspondence between sets of inputs and outputs as argued in neoclassical theory. This is because: "contracts for labour are incomplete, the production function is not completely specified or known, and not all factors of production are marketed (Leibenstein, 1968, p. 72).

Casson (1982, p. 23) defines the entrepreneurs as "someone who specializes in taking judgmental decisions about the coordination of scarce resources." And the essence of this judgmental decision is that there is no (superior) decision rule to apply. The outcomes of such decision depend on the entrepreneur who makes the decision. Casson's concept of entrepreneurship includes both the arbitraging activity described by Hayek and Kirzner, and the innovative activity described by Schumpeter (Casson, 1987).

In summary, although the notion of entrepreneurship is rather diverse among different scholars, some main features of it can be realised. They are who initiate businesses and who run businesses with Kirzner's arbitraging activities or Schumpeter's innovative activities. They are the main allocators of scarce resources in the economic system. And they are risk-taking people. Thus, all the functions of the entrepreneur are essential for any market economy. The pace of economic development ultimately depends on such endeavour of numerous entrepreneurs.

\section{Entrepreneurship and Economic Development}

With all the important features of entrepreneurship for the market process, entrepreneurship has been long recognised as an important factor of economic development. The entrepreneurial characteristics of competition, innovation and uncertaintybearing are indispensable inputs for market economies to flourish. It is normally believed that many developing countries lag behind because of their lack of entrepreneurship. The following sections elaborate the theoretical foundations on the role of entrepreneurship in 
economic development in particular and in the market process in general.

\subsection{Innovation and creative destruction}

The impact of entrepreneurial innovation on growth was clear in Schumpeter's writings. Schumpeter (1951) envisioned two states of an economy: a routine state and a state of development. A routine state of an economy is a situation without entrepreneurial innovation. It is 'a circular flow of economic life and conditioned by given circumstances.' It is a state that 'The individual household or firm acts, then, according to empirically given data and in an equally empirically determined manner...the economic system will not change capriciously on its own initiative but will be at all times connected with the preceding state of affairs. This may be called Wieser's principle of continuity' (Schumpeter 1951, pp.8-9). He argued that without entrepreneurship the economy kept running in the circular flow and no development took place. Schumpeter said: "Development in our sense is a distinct phenomenon, entirely foreign to what may be observed in the circular flow or in the tendency towards equilibrium. It is spontaneous and discontinuous change in the channels of the flow, disturbance of equilibrium, which forever alters and displaces the equilibrium state previously existing. Our theory of development is nothing but a treatment of this phenomenon and the process incident to it" (Schumpeter 1951, p.64).

The process of economic development was outlined by Schumpeter as the process of injecting innovative ideas into the economic system. Thus, entrepreneurship is a disturbing and driving force in the market system. Potentials for innovation are, to a large part, exogenous to the economic system. They may arise from basic inventions or from entrepreneurs' new ideas of organisation. Entrepreneurs seize these potentials for profit opportunities. They reap short-term monopoly profits for their innovations but these profits are soon bid away by imitative competitors. Development is seen as consisting of successive generations of innovation. He argued that entrepreneurship must be distinguished from invention. As long as they are not carried into practice by entrepreneurs, inventions are economically irrelevant.

Like Hayek and Mises in the Austrian tradition, Schumpeter emphasised the imperfection of knowledge. With limited knowledge, exact planning is impossible. Economic development depends on individuals to command resources in unconventional and innovative ways. The comparative efficiency of an economic system does not depend on its routine conduct but on how it generates innovation. Knowledge is empirical in the sense that entrepreneurs gain knowledge from experience. Schumpeter argued that innovation faced a great degree of uncertainty. It is this element of uncertainty that demands entrepreneurial spirit and leadership. He praised the entrepreneur for his role: "While in the accustomed circular flow every individual can act promptly and rationally because he is sure of his ground and is supported by the conduct, as adjusted to this circular flow, of all other individuals, who in turn expect the accustomed activity from him, he cannot simply do this when he is confronted by a new task. While in the accustomed channels his own ability and experience suffice for the normal individual, when confronted with innovation he needs guidance... Where the boundaries of routine stop, many people can go no further, and the rest can only do so in a highly variable manner...in describing the circular flow one must treat combinations of means of production as data, like natural possibilities, and admit only small variations at the margins, such as every individual can accomplish by adapting himself to changes in his economic environment, without materially deviating from familiar lines. Therefore, too, the carrying out of new combinations is a special function, and the privilege of a type of people who are much less numerous than all those who have the 'objective' possibility of doing it. Therefore, finally, entrepreneurs are a special type, and their behavior a special problem, the motive power of a great number of significant phenomena" (Schumpeter 1951, pp. 79-82).

Schumpeter argued that economic development in a market economy is a process 
of creative destruction. Innovation drives the economy ahead but at the same time destroys the old economic structures. He said: "The process of industrial mutation ... that incessantly revolutionizes the economic structure from within, incessantly destroying the old one, incessantly creating a new one. This process of Creative Destruction is the essential fact about capitalism" (Schumpeter 1965, p. 83). As such, Schumpeter criticised textbook microeconomics on competition. Essentially, economists saw competition as all about price competition. For him, the essential feature of competition should derive from innovation or new ideas. Creative destruction is the notable feature of capitalist development. Schumpeter's ideas of innovation have been picked up in recent studies on innovation and growth; notable among them are Aghion and Howitt (1998), Grossman and Helpman (1991), and Nelson and Winter (1982). Nevertheless, in order to keep it compatible with formalism, the notion of Schumpeterian innovation has been much narrower in these studies. In these models, Schumpeterian innovation is an important factor of growth.

\subsection{Knowledge, information,} entrepreneurship and the market process

The insights of Austrian economists like Mises, Hayek and Kirzner into the role of entrepreneurship on economic development originate from their understanding of the market process relating to imperfect knowledge, imperfect information, errors in human action, and subjectivism. In the presence of imperfect information and knowledge, the market system is characterised by disequilibrium and untapped gaps in the markets, which creates profit opportunities for entrepreneurs to exploit. The entrepreneur's alertness to exploit these untapped opportunities makes him the moving force in the market process. The market process is basically a discovery and entrepreneurial process. Kirzner (1973, 1997a,b) argued that it is this entrepreneurial discovery that eventually brings about equilibrium. In his words: "my own treatment of the entrepreneur emphasises the equilibrating aspects of his role. I see the situation upon which the entrepreneurial role impinges as one of inherent disequilibrium rather than of equilibrium - as one churning with opportunities for desirable changes rather than one of placid evenness. Although for me, too, it is only through the entrepreneur that changes can arise, I see these changes as equilibrating changes. For me the changes the entrepreneur initiates are always toward the hypothetical state equilibrium; they are changes brought about in response to the existing pattern of mistaken decisions, a pattern characterised by missed opportunities' (Kirzner 1973, p. 73). It is this entrepreneurial alertness that moves 'resources from one line of production to another, from less productive uses towards more productive uses' (Kirzner 1997a, p. 42).

In standard price theory, we assume that market participants know all the relevant information for market transactions, such as the kinds and qualities of goods and services available on the market, their prices, where and when to buy or sell them, etc. With such information, people formulate their own demand and supply functions. By totalling the supply and demand functions of individuals, we get supply and demand functions for the whole economy. And through the price mechanism, the market adjusts and is eventually in equilibrium, for each commodity and for the whole economy. However, the assumption of perfect information is unrealistic because in the real world no individual or organisation can have all the relevant information. Hayek (2002) maintained that market participants only gradually acquire more needed information in the process of competition. The market process is a constantly changing micro process. He said: “...various aggregates that macroeconomics treats as data are the result of microeconomic processes in which relative price changes play a decisive role. It is an outcome of the market mechanism that someone is induced to fill the gap that arises when someone else does not fulfil the expectations on the basis of which a third party has made plans. In this sense all the collective 
supply and demand curves that we use so happily are not really data, but rather outcomes of the constantly ongoing process of competition" (Hayek 2002, pp. 17-8). Information is highly dispersed and decentralised. New information always arises at every moment in time. And importantly, there is a cost in acquiring information. Therefore, market participants often make decisions in a situation of imperfect information. The process of competition is one of searching for information and utilising it. According to Hayek: "Competition is essentially a process of the formation of opinion by spreading information; it creates that unity and coherence of the economic system which we presuppose when we think of it as one market. It creates the views people have about what is best and cheapest and it is because of it that people know at least as much about possibilities and opportunities as they in fact do. It is thus a process which involves a continuous change in the data and whose significance must therefore be completely missed by any theory which treats these data as constant." (Hayek 1948, p. 106). For mainstream economics, when we lack information, we know what information we lack, and where to search for it, we know the costs of searching for such information and its usefulness. "Mainstream theory is then able to "explain" exactly how much additional information will be obtained, through deliberate, cost-benefit-calculative search" (Kirzner 1997a, p. 50). However, we do not know in advance what information we lack, we do not know where such information is available, and we do not know its costs and usefulness. It is only in the process of decision-making that we start to acquire such information.

Hayek (1945) argued that if we could possess all the relevant information and if we could command complete knowledge of available means, the problem of economic order would be purely one of logic. That is, the question as to what is the best use of the available means would already be answered in our assumptions. Put in their briefest of mathematical forms, they are that the marginal rates of substitution between any two commodities or factors must be the same in all their different uses. However, the problem of economic order is precisely the task of utilising information and knowledge not available to anyone in its totality. Hayek (1948) pointed out that the absence of the entrepreneur in neoclassical economics was ultimately related to its assumption of market equilibrium and perfect knowledge. Hayek argued that equilibrium could only exist in the condition of perfect knowledge. Because one person's decisions are the data of others' decisions, equilibrium merely means that the foresight of the different members of the society is correct. He said: "[E]quilibrium... exists if the actions of all members of the society over a period are all executions of their respective individual plans on which each decided at the beginning of the period" (Hayek 1937, p. 37). Hayek maintained that the nature of the market was an evolutionary process, stating: "[A]s all those other people will change their decisions as they gain experience about the external facts and other people's action, there is no reason why these processes of successive changes should ever come to an end" (Ibid., p. 48). And if equilibrium ever exists, it is just a temporary phenomenon and relative to one situation of knowledge: "This is that if the tendency towards equilibrium, which we have reason to believe to exist on empirical grounds, is only towards an equilibrium relative to that knowledge which people will acquire in the course of their economic activity..." (Ibid., p. 53). Moreover, Austrian economics argues that ignorance and errors are common in human action (Kirzner 1997b). Even when information is already available or costless to obtain, people may not know about it, or in other words they are ignorant of it or its existence. In the process of decision-making, errors are inevitable.

Austrian economists argued that the neoclassical competitive equilibrium framework could not capture the essence of the market process because it deals with given means and ends. The maximisation techniques in the given means and end framework do not allow for the role of entrepreneurship as an 
agent of active change. There is no discovery, no surprise or uncertainty in this framework. According to Mises (1949), in real economies we have to deal with highly complex phenomena of action. Action is temporal and means change. Action is to make choices and to cope with uncertainty. Action is aimed at influencing the future state of affairs, but depends on past and current data. Thus, any change in data in the immediate future will change the whole plan and course of action. The outcome of action is always uncertain and speculative. The outcomes of an economy are not rigid relationships of an evenly rotating system. They depend on the action of entrepreneurs. Mises asserted that: "It is impossible to eliminate the entrepreneur from the picture of a market economy. The various complementary factors of production cannot come together spontaneously. They need to be combined by the purposive efforts of men aiming at certain ends and motivated by the urge to improve their state of satisfaction. In eliminating the entrepreneur one eliminates the driving force of the whole market system" (Mises 1949, pp. 248-9). In his opinion, in real world economies differences between the sum of the prices of production factors and the prices of products emerge again and again. It is these changes that bring about potential profit opportunities for entrepreneurial discovery. The only source of entrepreneurial profit stems from the entrepreneur's ability in better anticipating future, uncertain events. If he fails in his understandings of future things to come, he is doomed.

In summary, the existence of imperfect information and imperfect knowledge, ignorance and errors are the reasons for market disequilibrium. In addition, the evolutionary nature of the market process makes equilibrium just a temporary phenomenon. It is because of this nature of the market process that the role of the entrepreneur becomes essential. The existence of disequilibrium gives rise to untapped opportunities that are the main sources for entrepreneurial discovery or entrepreneurial 'alertness' in the market process.

\subsection{Uncertainty, entrepreneurship and profit}

Knight (1971 [original 1921]) was a seminal work on uncertainty. He distinguished between risk and uncertainty. Risks can be measured with probability and can be secured with but uncertainty cannot. Each business situation is unique and has an element of uncertainty. It is this element of uncertainty that requires the adventure and judgment of entrepreneurs. The entrepreneur has to bear the costs of uncertainty. The profits are the rewards for his action of uncertainty-bearing. Knight said: "The background of the problem should now be clear: the uncertainty of all life and conduct which call for the exercise of judgment in business, the economy of division of labour which compels men to work in groups and to delegate the function of control as other functions are specialized, the facts of human nature which make it necessary for one who directs the activities of others to assume responsibility for the results of the operations, and finally the competitive situation which pits the judgment of each entrepreneur against that of the extant business world in adjusting the contractual incomes which he must pay before he gets anything for himself." (Knight 1971, p. 277). Knight argued that a managerial function became an entrepreneurial function when it assumed responsibility for errors of judgment. As such, the entrepreneur's uncertaintybearing activities contribute enormous saving to society and vastly increase the efficiency of economic production.

Like the Austrian economists, Knight argued that in a regularly rotating economy without uncertainty, entrepreneurial action is not required. "The succession of day and night or the alteration of the seasons, the vital processes and changes of our own lives, waking and sleeping, work-time and meal-time and play-time, infancy, maturity, and age such events call for action, but give rise to no problem of action; they are predictable. Problems of action arise out of departures from routine in changes of all sorts." (Knight 1971, p. 315). He admitted that imperfect knowledge was the most fundamental factor 
which gave rise to uncertainty. This argument is very much in line with Hayek and Mises. Mises (1949) argued that with perfect information and foresight, all entrepreneurs correctly would anticipate the future states of markets, and there would be no entrepreneurial profits. In Knight's opinion, for the entrepreneur, predicting the future conditions of markets to guide his action is one of the most uncertain aspects of entrepreneurial activities. This uncertainty is reduced with the entrepreneur's specialised knowledge and foresight. He said: "Uncertainty thus exerts a fourfold tendency to select men and specialize functions: (1) an adaptation of men to occupation on the basis of kind of knowledge and judgment; (2) a similar selection on the basis of degree of foresight, for some lines of activity call for this endowment in a very different degree from others; (3) a specialization within productive groups, the individuals with superior managerial ability (foresight and capacity of ruling others) being placed in control of the group and the others working under their direction; and (4) those with confidence in their judgment and disposition to 'back it up' in action specialize in risk-taking... We have not separated confidence and venturesomeness at all, since they act along parallel lines are little more than phases of the same faculty" (Knight 1971, p. 270).

With the specialisation of function, Knight distinguished two kinds of income: contractual income and the residual income, that is, profit. The entrepreneur receives profits for his specialised role. Mises (1949) argued that entrepreneurs faced uncertainty in the entrepreneurial discovery process. There is no guarantee that his search will be successful. If he succeeds, he gets rewarded with entrepreneurial profit, if he fails, he incurs losses. Mises (1949, p. 293) said: "The ultimate source from which entrepreneurial profit and loss are derived is the uncertainty of the future constellation of demand and supply." Mises argued that if we could calculate the future state of the market, the future would not be uncertain. There would be neither entrepreneurial loss nor profit. With the presence of uncertainty, entrepreneurial judgment becomes crucial. The entrepreneur believes that his judgement is better than that of others. That is why he is taking action. Mises maintained that entrepreneurial talent was a rare resource and could not be easily bought in the market.

In short, what makes the entrepreneur special is his uncertainty-bearing action and his belief in having better judgment than others in undertaking economic activities. Profit is the reward for his entrepreneurial efforts.

\subsection{The firm and entrepreneurship: judgemental decision and $X$-inefficiency}

In the words of Baumol (1968, 1993), the textbook theoretical firm is entrepreneurless. This arises from the neoclassical assumption of the existence of exogenous equilibrium and a well-defined solution to the problem of resource allocation. Baumol argues that using the calculus to present the entrepreneur as an automation maximiser leads nowhere in the analysis of entrepreneurship. He says: "the entrepreneur has been read out of the model. There is no room for enterprise or initiative. The management group becomes a passive calculator that reacts mechanically to changes imposed on it by fortuitous external developments over which it does not exert, and may not even attempt to exert, any influence. One hears of no clever ruses, ingenious schemes, valuable innovations, or any of the other stuff of which outstanding entrepreneurship is made; one does not hear of them because there is no way in which they can fit into the formal optimization model" (Baumol 1993, p. 13).

To further elaborate the role of entrepreneurship in firm performance, in this section, I present two main functions of entrepreneurship that directly influence firm performance: the problems of judgmental decision and $\mathrm{X}$-inefficiency. 


\section{Judgmental decision}

The function of the entrepreneur in judgmental decision has been emphasised and elaborated by Casson (2003, 1982). The essential feature of judgmental decision is that each business situation is unique and relative to each person's information and requires personal qualities and confidence to make decisions. This judgmental decision is the function of entrepreneurs. Casson (1987, p. 151) states that: "...not only is information costly, but the costs of acquiring information are different for different people. Furthermore, because their access to information differs, different people will make different decisions in the same situation. The essence of judgmental decision-making is that the outcome depends on who makes the decision." This understanding is in contrast to the postulate of neoclassical economics, where information is freely available and different people will make the same decision in the same situation due to this assumption and the optimisation technique in firm analysis. In the neoclassical framework, the entrepreneur is not needed because production had been optimised with a specified production function. Casson's entrepreneurs are not only self-employed but also salaried managers as long as they engage in judgmental decision. For Casson, judgmental decision is not made by the firm per se but by individuals - the entrepreneurs. By making judgmental decision, the entrepreneur acts as the coordinator of scarce resource allocation. Casson (2003) envisions co-ordination as a dynamic process as opposed to allocation as a static one. In this process, the entrepreneur is an agent of change. He is not concerned merely with existing allocation of resources, but with improvement on it.

Casson $(1987,2003)$ argues that much of information required for decision-making is not only costly to obtain, but also is not available by direct observation at all. This means that decisions are governed not only by objective information but also by subjective judgment of the entrepreneur. In a market economy, those who lack confidence tend to delegate decisions to entrepreneurs. Therefore, the entrepreneur is the central actor in the market system. It is he who moves the system ahead restlessly. He argues that the more complex the markets, the faster the pace of change, the greater will be the demand for entrepreneurs. Judgmental decision is needed for better allocation of resources. He argues: "...individuals differ not only in their tastes but in their access to information. Individuals with similar tastes, acting under similar circumstances, but with different information at their disposal, may well make different decisions. The entrepreneur exhibits an extreme form of this. The entrepreneur believes that the totality of the information available to him, in respect of some decision, is unique. On account of this, he will decide one way when everyone else would decide another. The entrepreneur believes that he is right, while everyone else is wrong. Thus the essence of entrepreneurship is being different - being different because one has a different perception of the situation. It is this that makes the entrepreneur so important. Were he not present, things would have been done very differently. In this way the entrepreneur's perception of the situation exerts a material influence on the allocation of resources" (Casson 2003, pp. 13-14).

The decision to establish a firm or not is a very entrepreneurial decision. Likewise, the decision to coordinate resources through the market or the firm is also a very entrepreneurial decision (Coase, 1937). The success of firms depends on the quality of judgmental decision, that is, entrepreneurship. According to Casson, however, entrepreneurship is scarce in society. He argues that some entrepreneurial qualities can be trained or learned from experience. But entrepreneurship is strongly influenced by personal qualities and desires. "A scarcity of personalities usually occurs, not because everyone has only a little of the quality, but because only a few people have the quality and many people do not have it all. In other words, scarcity is associated with skewness in the distribution of qualities between people. It is the possession of scarce qualities which confers an advantage on some people in 
becoming an entrepreneur" (Casson 2003, p. 29).

\section{X-inefficiency}

Like Baumol, Casson and other scholars writing on entrepreneurship in the firm, Leibenstein $(1968,1987)$ has recognised that the neoclassical competitive theory hides the vital function of the entrepreneur. The normal assumptions of the neoclassical competitive theory are that all inputs are marketed and their prices are known; that there is a definite production function relating inputs to outputs in a determinate and mechanical way. In these types of markets and firms, there is no room for the entrepreneur. Nevertheless, Leibenstein argued that there was no one-to-one correspondence between sets of inputs and outputs. The role of the entrepreneur is vital in the process of transforming inputs into outputs. Leibenstein (1987) argued that in general firms do not operate on their production possibility frontiers. $\mathrm{He}$ characterised this phenomenon as Xinefficiency: firms can increase output without increases in labour, capital, or other inputs. Xinefficiency measures the extent that a firm fails to materialise its productive potential. Xinefficiency theory identifies its major differences with neoclassical firm theory as follows: the production function is not completely specified or known, contracts for labour are incomplete, and not all factors of production are marketed (Leibenstein 1968). The firm is not a homogeneous entity, but consists of members with different roles and interests. The interaction between managers and employers and between employees has a considerable impact on the efficiency of firms. He said: 'The main elements affecting behavior are not usually the relation between the individual and the enterprise, but rather the almost invisible bonds and other relationships between individuals. In other words, the firm is not simply collection of isolated, visible contractual relationships between each employee and the enterprise. The informal connections between individuals in the organization are critical to our understanding of how efficiently a firm operates'
(Leibenstein 1987).

Leibenstein viewed the role of entrepreneurship as a creative response or solution to $\mathrm{X}$-inefficiency. $\mathrm{X}$-inefficiency means that some of the potential of a firm has been wasted, creating profit opportunities for entrepreneurial discovery to improve. Leibenstein (1968) identified two types of entrepreneurs. The first one is the Schumpeterian entrepreneur (which he called N-entrepreneurship) who makes 'new combinations.' The second one is a routine managerial function of firms. "Entrepreneurs working in the well-defined, non-hole, nonobstruction part of the net carry out routine entrepreneurial-managerial activities, while those that operate on the impeded, incomplete, and dark parts carry out N-entrepreneurial activities" (Leibenstein 1968, p. 77). He argued that the process of economic development was not merely a mechanical accumulation of production factors. Economic development involves both accumulation of productive resources and efficiency of using these resources (which we will call accumulation and assimilation later in this thesis). The process of accumulation of production factors and efficient use of them requires entrepreneurship. For the former, the entrepreneur contributes as an 'inputcompleter' and for the latter he contributes as a 'gap-filler.' Leibenstein's ideas on gap-filling entrepreneurs resemble the entrepreneurial function of alertness and discovery to untapped opportunities, which has been emphasised by Mises and Kirzner.

Leibenstein (1968) maintained that it was erroneous to think that the production function was clearly defined, fully specified and completely known. Imperfect information and knowledge were always serious. "Some gaps in markets are inherent in all cases" (Ibid., p. 74). To the extent that it is not completely known in reality, the entrepreneur must in some way fill in the deficiency. When a gap in information and knowledge exists, it is the profit signal that attracts entrepreneurs to fill it in. He also argued that not all important inputs of production were well marketed. 
Because of limited knowledge and information, it is also difficult to assess correctly the usefulness of inputs. Therefore, acquiring good inputs for productive purposes is an important part of the entrepreneurial function. In his opinion, "the entrepreneur has to employ some inputs that are somewhat vague in nature (but nevertheless necessary for production), and whose output is indeterminate." (Ibid., p. 74). One example is the employment contract. It is never possible to state clearly all aspects of employee work in the contract. "Usually the wages are specified but many aspects of the work, and work conditions, are left unspecified. Thus, effort is a variable open to some degree of discretionary choice by individual employees. As a result, employees are faced with numerous intracontract decisions about their own effort levels. The employment contract gets partly filled out on the job by adversarial, cooperative, or neutral relations between firm members." (Leibenstein 1987, pp. 22-3) According to Leibenstein, the implication of this is very serious for firm efficiency or Xefficiency: motivation is internal to the firm and not marketed, and some degree of slack causes low X-efficiency. Free-riding is another serious problem in employee-management and employee-employee relationships. And this problem is not easily detected either by managers or by employees due to incomplete information and knowledge. Both employees and employers may behave opportunistically. This is a kind of the prisoner's dilemma. Leibenstein said that "within each group there are free-rider incentives. That is, every employee may wish to work as little as possible in the interests of the firm, and deflect effort toward his own interests, even though, if he gave it some thought, he might desire all others to work effectively so the enterprise flourishes and his job and internal opportunities continue." (Leibenstein 1987, p. 57) A related issue is the divergence between employees' interests and company interests. This affects firm performance. Given the fact that firm performance depends on the effort of firm members, with this problem, effort and motivation are not materialised to the fullest extent. These ideas have now been well captured by New Institutional Economics. The principal-agent problem indicates possible dramatic divergence of interests between owners and managers of firms that may not lead to optimal performance. In the best interests of firm owners, managers should do their best to maximise profits. But in fact managers may do their best to maximise their incomes and career paths that may not necessarily lead to maximum profits. Moral hazard and adverse selection are other major reasons which lead to inefficiency. Moral hazard are defined as actions of economic agents maximising their own utility to the detriment of others, in other words, without bearing the full consequences of their actions due to asymmetric information and incomplete contracts. Adverse selection arises when there is asymmetric information on product quality between buyers and sellers (see, e.g., Akerlof, 1970). Normally sellers know more about product quality than buyers. The market ends up in inferior outcomes, mostly with lowquality products. Relating to Leibenstein's Xinefficiency, it is argued that in group production full assignment of responsibility to individuals is impossible and as such full assignment of consequences to individuals cannot be achieved. In addition, Leibenstein argued that people tend to be subject to inertia. That results in a path-dependent kind of behaviour, arising from personal habits, social conventions, etc. Inertia may entail nonoptimal behaviour and thus have a serious effect on efficiency. In summary, all the abovementioned problems make the relationship between inputs and outputs unspecified and inconstant. They are all sources for Xinefficiency of firms. Entrepreneurship is considered as a creative response and solution to this problem. In the words of Leibenstein: "...the efficiency of the firm will depend on internal entrepreneurship, which is the extent to which individual firm members have the capacity and take the initiative to put forth ideas that improve output, broadly defined. It will not matter if the hierarchy has a smooth system of procedures for making changes if individuals do not suggest any changes. Thus, 
ideas for improvements, and ideas for new projects to be undertaken by the enterprise depend on the capacity and willingness of individuals to be creative and to push such ideas" (Leibenstein 1987, p. 172).

In summary, entrepreneurship has different essential features that all are critical to growth and the market process. They are Kirzner's arbitragers or Schumpeter's innovators. They are Knight's uncertaintybearing people. They assume managerial or leadership roles and thus function as the main allocators of scarce resources in the economic system as identified by Baumol and Casson. Entrepreneurship is a solution to Xinefficiency, by motivating efforts within firms as argued by Leibenstein. All this has important implications for economic development.

\section{Summaries}

The role of entrepreneurship on economic development originated from different understandings on the nature of economic system. It is argued that the role of the entrepreneur has been moved out of the neoclassical model because a crucial assumption of the model is that decisionmaking merely involves marginalist calculation to optimise production, based upon public information supplied by the price system. The explanation for the phenomenon of economic development depends on how we understand the nature of the market process. In this respect, the economics of entrepreneurship is different from mainstream economics. For mainstream economics, the market is generally characterised by equilibrium; and mainstream growth economics is mainly about equilibrium growth, i.e., the movement from one equilibrium point to another equilibrium point. For the economics of entrepreneurship, the market process is characterised by disequilibrium. The main reasons for the market to be characterised by disequilibrium are those concerning with the issues of imperfect information and imperfect knowledge, ignorance, errors of market participants and the incessant innovation created by entrepreneurs. The stress here is on the role of entrepreneurship as the main driving force for the market process, hence economic development. Schumpeter's theory emphasises entrepreneurship as a disequilibrating force (through innovation) which drives the economic system forward. Kirzner (1973, 1997a,b) stresses entrepreneurship as an equilibrating force which exploits unnoticed opportunities, correcting errors in the market process. Therefore, entrepreneurship brings about higher values for resources used in the economy, and hence economic development.

The review of literature indicates that entrepreneurship has different essential features that all are critical to economic development and the market process. They are Kirzner's arbitragers or Schumpeter's innovators. They are Knight's uncertainty-bearing people. They assume managerial or leadership roles and thus function as the main allocators of scarce resources in the economic system as identified by Baumol and Casson. Entrepreneurship is a solution to $\mathrm{X}$-inefficiency, by motivating efforts within firms as argued by Leibenstein. All this has important implications for economic development. Millions of business decisions made by numerous entrepreneurs daily affect an economy a great deal. The pace of economic development ultimately depends on such endeavour of numerous entrepreneurs. It is normally believed that the lagging behind of many developing countries lies in their lack of entrepreneurship For developing countries, the catching-up role of entrepreneurship should be emphasised. Most of developing countries do not invent but learn to master technologies and practices from developed countries. Normally, an advanced technology or a good practice is not new to the world but new to a particular developing country. Thus, the ability of local entrepreneurs to imitate and learn rapidly is a critical factor for economic success of developing countries. The policy implication is that, in order to have good economic development, governments should create a favourable environment for entrepreneurs to carry out above-mentioned functions in the economy. 


\section{REFERENCES}

Aghion, P. and Howitt, P. (1998). Endogenous Growth Theory. Cambridge: The MIT Press.

Akerlof, G. A. (1970). "The Market for "Lemons". Quality Uncertainty and the Market Mechanism', Quarterly Journal of Economics, Vol. LXXXIV, pp. 488-500.

Baumol, W. J. (1968). "Entrepreneurship in Economic Theory". American Economic Review, Vol. 58, pp. 64-71.

Baumol, W. J. (1990). "Entrepreneurship: Productive, Unproductive, and Destructive". Journal of Political Economy, Vol. 98, October, pp. 893-921.

Baumol, W. J. (1993). Entrepreneurship, Management, and the Structure of Payoffs. Cambridge, Massachusetts and London: the MIT Press.

Binks, M. and Vale, P. (1990). Entrepreneurship and Economic Change. England: McGraw-Hill.

Cantillon, R. (1755). "The Circulation and Exchange of Goods and Merchandise", reprinted in Casson, M. (ed.) (1990). Entrepreneurship, Aldershot: Elgar.

Casson, M. (1982). The Entrepreneur: An Economic Theory. Oxford: Martin Robertson.

Casson, M. (1987). "Entrepreneur”, in Eatwell, J., Milgate, M., and Newman, P. (eds.) (1987). The New Palgrave: a Dictionary of Economics: London: S.N.

Casson, M. (2003). The Entrepreneur: An Economic Theory. Second Edition, Cheltenham and MA: Edward Elgar.

Casson, M. (ed.) (1990). Entrepreneurship. Aldershot: Edward Elgar.

Coase, R. H. (1937). “The Nature of the Firm”. Economica, IV, November, pp. 386-405.

Grossman, G. M. and Helpman, E. (1991). Innovation and Growth in the Global Economy. Cambridge, MA: MIT Press.

Hayek, F. A. (1935). Collectivist Economic Planning: Critical Studies on the Possibilities of Socialism. London: Routledge.

Hayek, F. A. (1937). “Economics and Knowledge”. Enonomica, New Series, Vol. 4, pp. 33-54.

Hayek, F. A. (1945). "The Use of Knowledge in Society". American Economic Review, Vol. XXXV, No. 4, September, pp.521-54.

Hayek, F. A. (1948). Individualism and Economic Order. Chicago: University of Chicago Press.

Hayek, F. A. (1952). The Counter-Revolution of Science: Studies in the Abuse of Reason. Illinois: The Free Press.

Hayek, F. A. (1974). "The Pretence of Knowledge". Nobel Memorial Lecture, delivered at Stockholm, 11 December 1974, reprinted in Littlechild (1990).

Hayek, F. A. (2002). "Competition as A Discovery Procedure”, translated by Marcellus S. Snow from Hayek's 1968 lecture 'Der Wettbewerb als Entdeckungsverfahren' at the University of Kiel. Quarterly Journal of Austrian Economics, Vol. 5, No. 3, pp. 9-23.

Hirschman, A. (1958). The Strategy of Economic Development. New Haven, Conn.: Yale University Press. 
Kirzner, I. M. (1973). Competition and Entrepreneurship. Chicago and London: The University of Chicago Press.

Kirzner, I. M. (1982). Method, Process, and Austrian Economics. Lexington, MA: Lexington Books.

Kirzner, I. M. (1990). "On the Methods of Austrian Economics”, in Littlechild (1990). Austrian Economics, Volume I, Aldershot: Edward Elgar.

Kirzner, I. M. (1997a). How Markets Work: Disequilibrium, Entrepreneurship, and Discovery. London: The Institute of Economic Affairs.

Kirzner, I. M. (1997b). "Entrepreneurial Discovery and the Competitive Market Process: An Austrian Approach". Journal of Economic Literature, Vol. XXXV, March, pp. 60-85.

Knight, F. H. (1971 [original 1921]). Risk, Uncertainty and Profit. Chicago and London: University of Chicago Press.

Leibenstein, H. (1957). Economic Backwardness and Economic Growth. New York: John Wiley \& Sons, Inc.

Leibenstein, H. (1968). "Entrepreneurship and Development”. American Economic Review, Vol. 58 , pp. $72-83$.

Leibenstein, H. (1976). Beyond Economic Man: A New Foundation of Microeconomics. Massachusetts and London: Harvard University Press.

Leibenstein, H. (1987). Inside the Firm: the Inefficiencies of Hierarchy. Massachusetts and London: Harvard University Press.

Mises, L. V. (1949). Human Action: A Treatise on Economics. New Haven: Yale University Press.

Nelson, R. R. and Winter, S.G. (1982). An Evolutionary Theory of Economic Change. Cambridge, MA: Harvard University Press.

Rostow, W. W. (1960). The Stages of Economic Growth: A Non-Communist Manifesto. Fifteenth Printing, 1967, Cambridge: At The University Press.

Schumpeter, J. A. (1951) [Original 1911]. The Theory of Economic Development. Cambridge, MA: Harvard University Press.

Schumpeter, J. A. (1965). Capitalism, Socialism and Democracy. London: Unwin University Books.

Wennekers, S., Thurik, R., Buis, F. (1997). Entrepreneurship, Economic Growth, and What Links Them Together. Zoetermeer: EIM / Small Business Research and Consultancy.

Yu, T. Fu-Lai (1997). Entrepreneurship and Economic Development in Hong Kong. London and New York: Routledge. 